\title{
In vivo evaluation of the inhibitory capacity of human plasma on exogenous surfactant function
}

\author{
B. Lachmann, E.P. Eijking, K. L. So, D. Gommers \\ Department of Anesthesiology, Room Ee 2393, Erasmus University, P. O. Box 1738, NL-3000 DR Rotterdam, The Netherlands
}

Received: 17 December 1992/Accepted: 28 June 1993

\begin{abstract}
Objective: The adult respiratory distress syndrome (ARDS) and neonatal respiratory distress syndrome (RDS) are characterized by high permeability pulmonary edema which contains plasma-derived proteins inhibiting pulmonary surfactant function. Currently, discussion continues as to what dose of surfactant is required for treatment of these syndromes.

Design: The purpose of this study was to investigate the amount of exogenous surfactant needed to overcome the inhibitory components in human plasma. Male adult rats suffering from respiratory failure due to surfactant depletion after whole-lung lavage received human plasma ( $4 \mathrm{ml} / \mathrm{kg}$ body weight) mixed with surfactant at different concentrations, intratracheally. Rats receiving surfactant only at different concentrations served as controls. Blood gas analysis was performed.

Measurements and results: It was demonstrated that plasma $(4 \mathrm{ml} / \mathrm{kg} \approx 273 \mathrm{mg}$ plasma proteins $/ \mathrm{kg}$ ) mixed with surfactant at $300 \mathrm{mg} / \mathrm{kg}$ was able to increase and maintain $\mathrm{PaO}_{2}$ at normal values. Plasma mixed with surfactant at $100 \mathrm{mg} / \mathrm{kg}$, after initial restoration of blood gases, showed deterioration of $\mathrm{PaO}_{2}$ values. Plasma mixed with surfactant at a dose of $50 \mathrm{mg} / \mathrm{kg}$ did not improve $\mathrm{PaO}_{2}$ whereas surfactant at $50 \mathrm{mg} / \mathrm{kg}$, without plasma, restored blood gases to pre-lavage values.

Conclusion: It is concluded that approximately $1 \mathrm{mg}$ surfactant phospholipids is required to overcome the inhibitory effect of approximately $1 \mathrm{mg}$ plasma proteins. For clinical practice this means that an excess of surfactant should be given, or repeatedly be substituted ("titrated") at low concentrations, until blood gases improve.
\end{abstract}

Key words: Animal model - Blood gases - Respiratory failure - Exogenous surfactant therapy - Surfactant inhibition - Plasma proteins

This work was financially supported by the Dutch Foundation for Medical Research

Correspondence to: Prof. Dr. Dr. B. Lachmann
The adult respiratory distress syndrome (ARDS) and neonatal respiratory distress syndrome (RDS) are both characterized by respiratory failure and require therapy consisting of intubation and mechanical ventilation with high oxygen concentrations. RDS is characterized by primary surfactant deficiency due to immaturity of the lungs, while in ARDS high permeability pulmonary edema exists, containing plasma-derived proteins which inhibit pulmonary surfactant function [1-7]. Due to impaired surfactant function, surface tension at the air-liquid interphase on the alveolar walls is increased, leading to an increased pressure gradient across the alveolar-capillary membrane, favouring further accumulation of protein-rich edema fluid into the alveolar space [8].

Several clinical trials have reported successful treatment with intratracheal surfactant instillation in prematures suffering from RDS $[9-14]$. In these studies, however, some infants did not respond to a single dose of surfactant and some infants had an only transient improvement of lung function $[10,11]$. One reason for this could be that surfactant function is inhibited by plasmaderived proteins present in intra-alveolar edema fluid.

A few reports on ARDS patients treated with surfactant have been published. Although the results from these studies are not consistent, the best results were seen in those patients treated with higher surfactant concentrations [15-19].

Currently, discussion continues as to what dose of surfactant should be used in prematures with established RDS and what dose should be used for treatment of ARDS. To investigate this, a study was performed in an animal model of respiratory failure induced by bronchoalveolar lavage (BAL). This model has proven useful for a variety of experimental purposes including, e.g. testing of different surfactant preparations and demonstrating that exogenous surfactant restores blood gases to normal [20-22]. After respiratory failure was established, animals received plasma mixed with surfactant at different concentrations. Plasma was used to simulate proteinrich edema, an established characteristic of ARDS. Instead of lung mechanics, blood gas measurements were 
measured, since these have proven to be more sensitive to therapeutic interventions in this model [23].

\section{Materials and methods}

\section{Materials}

The surfactant used in these experiments was a freeze-dried natural surfactant isolated from bovine lungs in basically the same manner as previously described [24]. It consists of approximately $90 \%$ phospholipids, $1 \%$ hydrophobic proteins (SP-B and SP-C), the remainder being other lipids such as cholesterol, glyceride and free fatty acids. There is no SP$A$ in this surfactant preparation. This surfactant preparation has proven to be highly effective in improving gas exchange and lung mechanics in various animal models of respiratory failure of different etiologies $[25-27]$ and in newborn babies suffering from respiratory failure due to congenital diaphragmatic hernia [28].

Pooled citrated plasma was collected from healthy volunteers and prepared according to standard techniques. Protein concentration was measured using a modified Lowry method [29], with bovine serum albumin as standard. Protein concentration of the pooled plasma was $68.3 \mathrm{mg} / \mathrm{ml}$.

\section{Animal study}

The protocol was approved by the Animal Care and Use Committee of the Erasmus University Rotterdam.

The studies were performed in 45 male adult Sprague-Dawley rats (body weight $300-350 \mathrm{~g}$ ). After induction of anesthesia with nitrous oxide, oxygen and halothane $(65 / 33 / 2 \%)$ the animals were tracheotomized and a catheter was inserted into the carotid artery. Anesthesia was maintained with pentobarbital sodium $(60 \mathrm{mg} / \mathrm{kg} / \mathrm{h}$, i.p.) and muscle relaxation was attained with pancuronium bromide $(0.5 \mathrm{mg} / \mathrm{kg} / \mathrm{h}$, i.m.). The rats were ventilated with a Servo Ventilator $900 \mathrm{C}$ (SiemensElema, Solna, Sweden) at the following ventilator settings: pressure-controlled ventilation, $\mathrm{FIO}_{2}=1.0$, ventilation frequen$\mathrm{cy}=30 / \mathrm{min}$, peak airway pressure $\left(\mathrm{P}_{\text {peak }}\right)=14 \mathrm{cmH}_{2} \mathrm{O}$, positive endexpiratory pressure (PEEP) $=2 \mathrm{~cm} \mathrm{H}_{2} \mathrm{O}$ and inspiratory/expiratory ratio $=1: 2$.

After reaching steady state $\left(\mathrm{PaO}_{2}>500 \mathrm{mmHg}\right)$ respiratory failure was induced by BAL as described by Lachmann et al. [20]. In brief: lungs were lavaged $6-7$ times with warm saline $\left(37^{\circ} \mathrm{C} ; 30 \mathrm{ml} / \mathrm{kg}\right)$ to produce a $\mathrm{PaO}_{2}<80 \mathrm{mmHg}$ at $\mathrm{P}_{\text {peak }}=26 \mathrm{cmH}_{2} \mathrm{O}$ and $\mathrm{PEEP}=$ $6 \mathrm{cmH}_{2} \mathrm{O}$. These ventilator settings were unchanged throughout the entire observation period.

Approximately 5 min after $\mathrm{PaO}_{2}<80 \mathrm{mmHg}$ animals were randomly divided into seven groups: after disconnection from the ventilator, Groups I, II, and III ( $n=6, n=7$ and $n=7$, respectively) immediately received intratracheally the undiluted plasma $(4 \mathrm{ml} / \mathrm{kg}=273.2 \mathrm{mg}$ plama proteins $/ \mathrm{kg}$ ) mixed with surfactant at concentrations of 50,100 and $300 \mathrm{mg}$ phospholipids/ $\mathrm{kg}$ body weight, respectively; Groups IV, V and VI ( $n=6, n=6$ and $n=7$, respectively) received surfactant suspended in saline at concentrations of 25,50 and $100 \mathrm{mg}$ phospholipids/ $\mathrm{kg}$ body weight, respectively (total amount of surfactant suspension was $4 \mathrm{ml} / \mathrm{kg}$ ); Group VII $(n=6)$ received undiluted plasma $(4 \mathrm{ml} / \mathrm{kg})$, intratracheally. In all groups intratracheal instillation was followed by a bolus of air $(32 \mathrm{ml} / \mathrm{kg})$, and mechanical ventilation was continued. Before intratracheal instillation, surfactant-plasma mixtures were incubated for $30 \mathrm{~min}$ at $37^{\circ} \mathrm{C}$.

Blood samples for measurement of $\mathrm{PaO}_{2}$ and $\mathrm{PaCO}_{2}$ were taken from the carotid artery before $\mathrm{BAL}$ and $5 \mathrm{~min}$ after the last lavage (directly followed by treatment) and at $5,30,60,90,120,150$ and $180 \mathrm{~min}$ post-treatment (ABL 330; Radiometer, Copenhagen, Denmark). The animals were then sacrificed with an overdose of intraarterially administered pentobarbital sodium.

\section{Statistical analysis}

All data are expressed as mean \pm standard deviation (SD). Statistical analysis of data was performed using repeated measurements Anovas, with time as the repeat variable. When differences between and/or within groups occurred, these differences were further analyzed with a test that compensated for multiple comparison (Student-Newman-Keuls test). Statistical significance was accepted at $p \leq 0.05$.

\section{Results}

Figures $1 \mathrm{a}$ and $1 \mathrm{~b}$ show $\mathrm{PaO}_{2}$ values for all groups. The intergroup differences both before and after lavage are not statistically different. After treatment, the $\mathrm{PaO}_{2}$ values of groups receiving surfactant only at 50 and $100 \mathrm{mg} / \mathrm{kg}$ (Groups V and VI, respectively) increase to pre-lavage values and remain high during the whole observation period and the differences between these groups are not significant; for this reason $\mathrm{PaO}_{2}$ values of these two groups are used for statistical comparison with other groups. Surfactant only at $25 \mathrm{mg} / \mathrm{kg}$ (Group IV), after initial improvement to pre-lavage values, did not stabilize $\mathrm{PaO}_{2}$ values over the whole observation period; the difference with Groups V/VI was significant after $60 \mathrm{~min}$. $\mathrm{PaO}_{2}$ values of rats reveiving plasma $(4 \mathrm{ml} / \mathrm{kg})$ mixed with surfactant at 100 and $300 \mathrm{mg} / \mathrm{kg}$ (Groups II and III, respectively) also increase to normal values. Immediately after treatment there is no significant difference in $\mathrm{PaO}_{2}$ values between Groups II and III and Groups V/VI. However, $\mathrm{PaO}_{2}$ values of Group II decrease significantly 60 min after treatment compared to Group III. $\mathrm{PaO}_{2}$ values of Group III remain at high levels throughout the observation period and are not significantly different from Groups V/VI. $\mathrm{PaO}_{2}$ values of rats receiving plasma mixed with surfactant at $50 \mathrm{mg} / \mathrm{kg}$ (Group I) did not increase significantly. Rats receiving plasma only (Group VII) died within $60 \mathrm{~min}$.

Figures $2 \mathrm{a}$ and $2 \mathrm{~b}$ show the $\mathrm{PaCO}_{2}$ values for all groups. The intergroup differences both before and after lavage are not statistically different. $\mathrm{PaCO}_{2}$ values of rats receiving surfactant only at 50 or $100 \mathrm{mg} / \mathrm{kg}$ do not differ significantly, and are used for comparison with other groups. $\mathrm{PaCO}_{2}$ values of Groups I, II and VII differ significantly from Groups V/VI. There is no significant difference in $\mathrm{PaCO}_{2}$ values between Group III and Groups V/VI. There are no significant differences in $\mathrm{PaCO}_{2}$ values between Groups II and III.

\section{Discussion}

It has been established that in both ARDS and RDS the alveolar-capillary membrane is highly permeable to plasma proteins, leaking from the circulation into the alveolar space, resulting in edema formation $[2,30,31]$. BAL material of patients suffering from these syndromes demonstrates quantitative and qualitative changes in phospholipid composition of surfactant, and contains high protein concentrations $[2,31-35]$. Saline extracts of lung minces from infants who died from RDS and from adults with ARDS contained less phospholipids and had higher minimal surface tension than similar extracts from lungs of patients who died from other causes [15, 36]. Several clinical studies have been performed treating infants suffering from RDS with intratracheal surfactant instillation [9.14]. The surfactant preparations used var- 

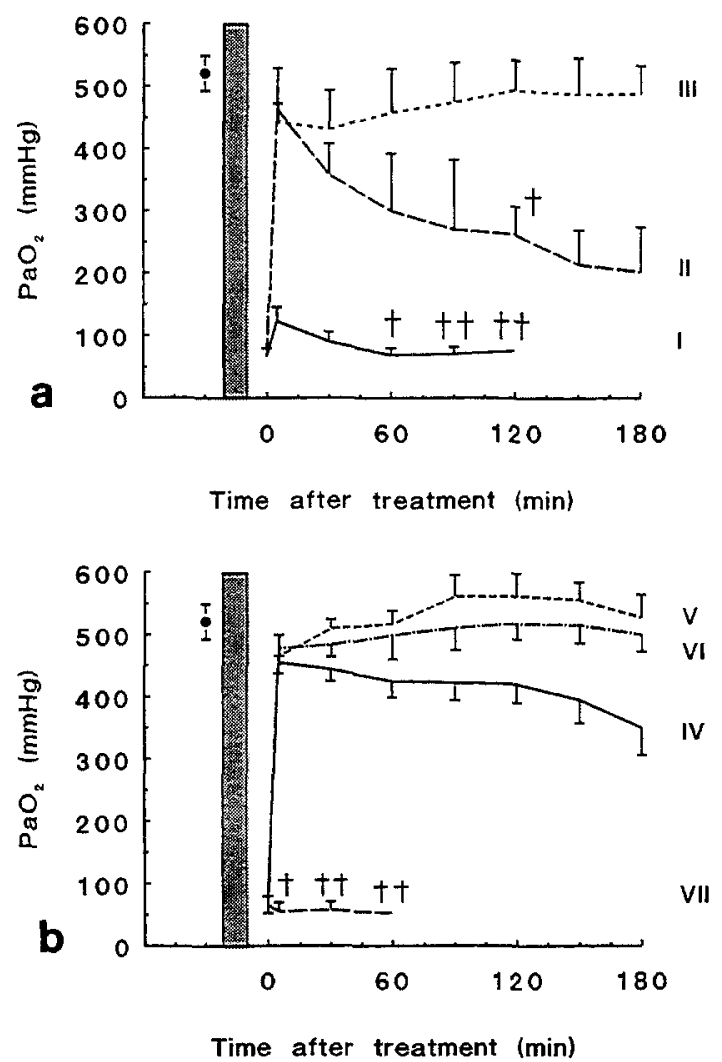

Fig. 1a,b. $\mathrm{PaO}_{2}$ values (mmHg; mean $\pm \mathrm{SD}$ ) before $(\bullet$ ) and after BAL ( = grey bar) in different treatment groups: Groups I, II, and III receivedplasma $(4 \mathrm{ml} / \mathrm{kg})$ mixed with surfactant at 50,100 and $300 \mathrm{mg} / \mathrm{kg}$, respectively (a); Groups IV, V and VI received surfactant only at 25,50 and $100 \mathrm{mg} / \mathrm{kg}$, respectively and Group VII received plasma only $(4 \mathrm{ml} / \mathrm{kg})(\mathrm{b}) ; \mathrm{t}=0$ indicates the $\mathrm{PaO}_{2}$ values $5 \mathrm{~min}$ after $\mathrm{BAL}$, immediately followed by treatment; $\dagger=$ one rat died; $\mathrm{PaO}_{2}=$ arterial oxygen tension.

ied from natural surfactant (e.g. CLSE, Curosurf, Surfactant TA and human surfactant) to synthetic surfactant preparations (ALEC, Exosurf). The doses used in these clinical trials varied from low $(60 \mathrm{mg} / \mathrm{kg})$ to high $(200 \mathrm{mg} / \mathrm{kg}$ ). It has been reported that some infants did not respond to, or had an only transient improvement after a single treatment of low-dose surfactant $[10,11]$. It has been suggested that in these patients increased permeability of the alveolar-capillary membrane leads to accumulation of plasma proteins in the alveolar space, causing inhibition of the surfactant preparation. This hypothesis could be confirmed in other clinical studies in which better clinical outcome was seen in infants treated with either a higher dose of surfactant [11] or by treatment with multiple doses [14]. Only a few patients with ARDS have been treated with surfactant. Although the results from these studies are not consistent, the best results were seen in patients treated with higher surfactant concentrations [15-19].

After treatment of RDS and ARDS with a low dose of surfactant the reason for lack of response, or only transient improvement, is attributed to the alveolar space in these patients being filled with protein-rich edema fluid. Clinical and animal studies have established that these plasma-derived proteins inhibit surfactant $[1-7,30,31$,
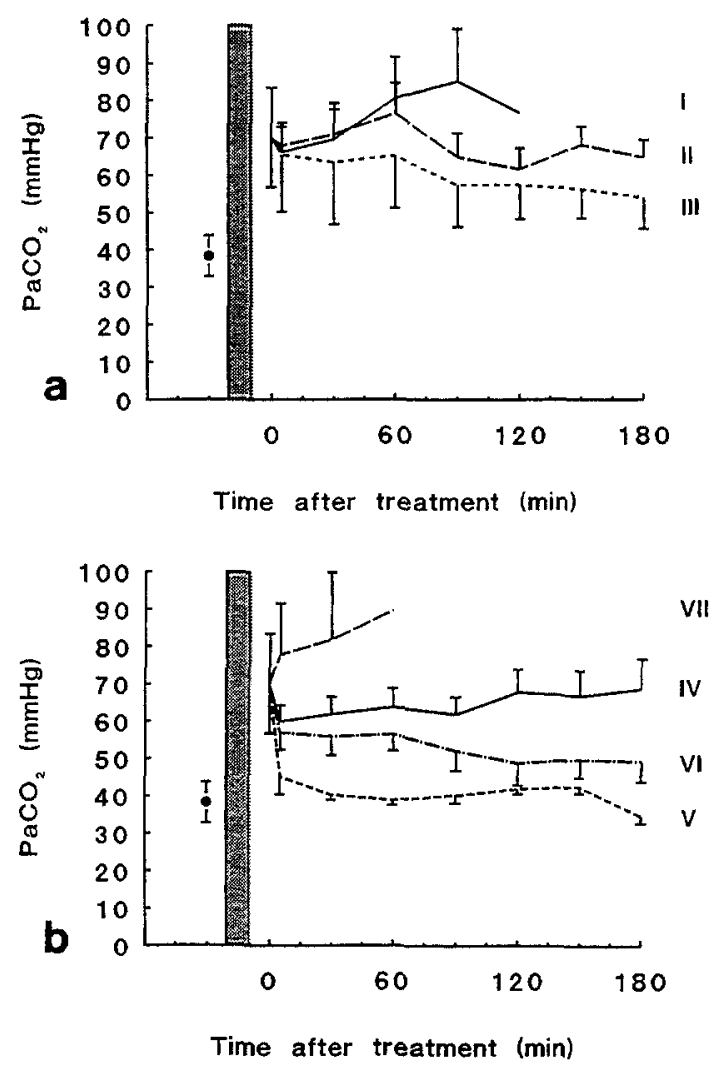

Fig. 2a, b. $\mathrm{PaCO}$, values (mmHg; mean $\pm \mathrm{SD}$ ) before $(\bullet$ ) and after $\mathrm{BAL}$ ( = grey bar) in different treatment groups: for explanation of groups, see Fig. $1 ; \mathrm{PaCO}_{2}=$ arterial carbon dioxide tension

37-41]. Surface tension studies have shown that several plasma proteins inhibit surfactant in a dose-dependent manner [7, 38, 39, 42-47]. It is also established that some surfactant preparations, especially synthetic surfactants, are more sensitive to the inhibitory effect of plasma-derived proteins than other preparations [48-50]. However, in recent studies it was demonstrated that addition of surfactant-associated proteins increases resistance of synthetic surfactants to inhibition of plasma proteins [51, 52]. In physiological studies using excised lungs it was shown that intratracheal instillation of hemoglobin, albumin or membrane lipids decreased lung compliance, which could be reversed by intratracheal surfactant instillation [44].

The mechanism by which plasma derived proteins inhibit surfactant function is not clear. Balis and colleagues [53] have postulated two different types of surfactant inhibition. They demonstrated that inhibition of surfactant by serum could be reversed by centrifugating the surfactant-serum mixture: the sediment revealed normal surfactant function. Mixing surfactant with plasma allowed clot formation to occur; this "coagulative type" of inhibition could not be reversed by centrifugation. Seeger and colleagues reported that fibrin monomers are potent inhibitors of surfactant; inhibition of surfactant could partially be reversed by adding plasmin to the fibrin-surfactant mixture [7]. Other investigators have hypothesized that inhibition of surfactant by plasma derived proteins is due to competition for space at the air-liquid in- 
terphase. Holm and colleagues reported that at high surfactant concentrations the inhibitory effect of high concentrations of plasma proteins or membrane lipids is abolished $[44,45]$. The reason for this observation is not known. Other studies confirm the probable existence of a competition mechanism: after centrifugation of surfactant-inhibitor mixtures derived from BAL fluid of animals treated with surfactant or after centrifugation of surfactant-protein mixtures, the sediments containing surfactant revealed normal surface tension characteristics compared with before centrifugation $[2,37,40,45,53]$. Also, when these BAL fluids or the surfactant-protein mixtures were investigated for surface tension properties, it could be demonstrated that after a certain number of cycles the minimal surface tension decreased from initially high levels to low levels $[7,38,41,42]$. These findings probably indicate that, if there is any chemical interaction between proteins and surfactant, this interaction is not strong.

If the mechanism of competition between surfactant and plasma proteins is correct, then this would be of great importance for treatment of ARDS and neonatal RDS. Namely, whether the lungs are filled with plasmaderived proteins or not, intratracheal instillation of sufficiently high doses of surfactant should restore lung function. Surfactant treatment of animals with enormous amounts of pulmonary edema caused by prolonged exposure of $100 \%$ oxygen or hydrochloric acid $(\mathrm{HCl})$ aspiration does not seem to have any positive influence on restoring gas exchange at the concentrations used [1, 4]. Kobayashi and colleagues have demonstrated that surfactant treatment was only able to restore gas exchange in rabbits suffering from respiratory failure after $\mathrm{HCl}$ aspiration after lungs had been lavaged, this way removing proteins from the alveolar space [4]. This strongly suggests that a more favorable surfactant/inhibitor ratio was established after lung lavage followed by surfactant treatment. In another study, surfactant instillation at very high doses $(280-350 \mathrm{mg} / \mathrm{kg})$ was able to restore gas exchange in guinea pigs suffering from severe respiratory failure due to high permeability pulmonary edema after intravenous instillation of anti-lung serum [54]; thus a more favorable surfactant/inhibitor ratio was obtained by giving a large amount of surfactant. Recently, Kobayashi and colleagues investigated the capability of porcine surfactant mixed with edema fluid at several ratios to restore lung function in immature rabbit fetuses, as measured by tidal volume at preset insufflation pressures [5]. It was demonstrated that surfactant $(25 \mathrm{mg} / \mathrm{ml})$ mixed with edema fluid at a protein to lipid ratio (P/L ratio) of 2.2 was capable of restoring lung function, whereas surfactant mixed with edema fluid at $\mathrm{P} / \mathrm{L}$ ratio of 11.2 , was not. Surface tension properties of these mixtures demonstrated high minimal surface tensions at $\mathrm{P} / \mathrm{L} \geq 3.4$ and low surface tensions at $\mathrm{P} / \mathrm{L} \leq 1.8$. In the present study a $\mathrm{P} / \mathrm{L}$ ratio of 0.9 (Group III) was capable of restoring gas exchange over the 3 hour observation period, whereas at $\mathrm{P} / \mathrm{L}$ ratio of 2.7 (Group II) there was only transient improvement. At $\mathrm{P} / \mathrm{L}$ ratio of 5.5 (Group I), no improvement was seen. Our results are in concordance with the observations reported by Kobayashi and col- leagues, although a different animal model looking at different parameters and a different surfactant preparation were used [5]. The results confirm the hypothesis of the competition mechanism between surfactant and proteins, although it cannot be ruled out that some direct interaction between surfactant and proteins occurs.

The lung lavage model, used in the present study, has proven useful for a variety of experimental purposes, including e.g. testing of different surfactant preparations and demonstrating that exogenous surfactant restores blood gases to normal [20-22]. In this model, the concentration of the surfactant preparation (which is more or less comparable with all other natural surfactant preparations) needed to restore blood gases over a 3 hour observation period was $50 \mathrm{mg} / \mathrm{kg}$ (Fig. 1 B). To get the same results when surfactant was mixed with human plasma ( $4 \mathrm{ml} / \mathrm{kg} \approx 273 \mathrm{mg}$ plasma proteins $/ \mathrm{kg}$ ), six times as much surfactant $(300 \mathrm{mg} / \mathrm{kg})$ was necessary to restore and stabilize gas exchange (Fig. 1 A). This means that approximately $1 \mathrm{mg}$ surfactant phospholipids is needed to overcome the inhibitory effect of $1 \mathrm{mg}$ plasma proteins. Surfactant at $100 \mathrm{mg} / \mathrm{kg}$ initially restored gas exchange, however appeared not to be enough to overcome the additional inhibition by plasma proteins leaking into the alveolar space. Because of this, gas exchange deteriorated after initial improvement. In these experiments citrated plasma was used to obtain full inhibitory capacity, in cluding fibrinogen. However, the inhibitory components in diseased lungs probably consist not only of products derived from blood but also consist of, for example, specific proteases, inflammatory mediators, bacteria, membranes, etc. Plasma-derived proteins, however, may be the most important compounds of high-permeability edema fluid and thus, from this point of view, it makes sense to "titrate" the amount of surfactant for replacement therapy by mixing it with full plasma.

Our results favor the competition hypothesis: when mixed with plasma, surfactant at $50 \mathrm{mg} / \mathrm{kg}$ shows no improvement, at $100 \mathrm{mg} / \mathrm{kg}$ there is only transient improvement, and at $300 \mathrm{mg} / \mathrm{kg}$ there is sustained improvement of blood gas values. These results imply that for treatment of ARDS or established RDS a high concentration of surfactant is required to overcome the inhibitory effect of plasma-derived proteins. If after surfactant instillation there is no, or only transient, improvement of blood gas values in patients with either ARDS or RDS (fibrotic lungs excluded) this does not mean that surfactant treatment does not work. It only means that the concentration of the surfactant preparation used is too low in relation to the amount of surfactant inhibitors in the lungs. This raises the question of how to exclude the existence of fibrotic lungs. In our clinical practice we investigate this as follows: we increase the mean airway pressure in mechanically ventilated patients and observe blood gases. If blood gases improve this would mean that there are still recruitable lung parts which could be stabilized by exogenous surfactant treatment. On the other hand, if blood gases remain stable or even deteriorate after increasing mean airway pressure due to further mismatch of the ventilation/perfusion ratio, surfactant instillation may worsen the clinical situation by filling up the remaining areas 
participating in gas exchange, which is typical for fibrotic lungs. Thus, before giving surfactant, especially after a long period of artificial ventilation ( $2-3$ weeks), one should always examine if there is still some lung tissue left which can be recruited by high ventilation pressures. As a consequence, in treatment of ARDS or established RDS: i) surfactant should be given as early as possible and ii) an excess of surfactant should be given, or repeatedly be substituted ("titrated") at low concentrations until blood gases improve.

Acknowledgements. We thank Arie Kok for expert technical assistance and Laraine Visser-Isles for English language editing.

\section{References}

1. Ennema JJ, Kobayashi T, Robertson B, Curstedt T (1988) Inactivation of exogenous surfactant in experimental respiratory failure induced by hyperoxia. Acta Anaesthesiol Scand 32:665-671

2. Ikegami M, Jacobs H, Jobe A (1983) Surfactant function in respiratory distress syndrome. J Pediatr 102:443-447

3. Johnson JWC, Permutt S, Sipple JH, Salem ES (1964) Effect of intra-alveolar fluid on pulmonary surface tension properties. J Appl Physiol 19:769-777

4. Kobayashi T, Ganzuka M, Tanigushi J, Nitta K, Murakami S (1990) Lung lavage and surfactant replacement for hydrochloric acid aspiration in rabbits. Acta Anaesthesiol Scand 34:216-221

5. Kobayashi $T$, Nitta $K$, Ganzuka $M$, Inui $S$, Grossmann $G$, Robertson B (1991) Inactivation of exogenous surfactant by pulmonary edema fluid. Pediatr Res 29:353-356

6. Said SI, Avery ME, Davis RK, Banerjee CM, El-Cohary M (1965) Pulmonary surface activity in induced pulmonary edema. $\mathrm{J}$ Clin Invest 44:458-464

7. Seeger W, Stöhr G, Wolf HRD, Neuhof $H$ (1985) Alteration of surfactant function due to protein leakage: special interaction with fibrin monomer. J Appl Physiol 58:326-338

8. Guyton AC, Moffatt DS, Adair TH (1984) Role of alveolar surface tension in transepithelial movement of fluid. In: Robertson B, Van Golde LMG, Batenburg JJ (eds) Pulmonary surfactant. Elsevier, Amsterdam, pp 171-185

9. Fujiwara T, Chida S, Watabe Y, Maeta H, Morita T, Abe T (1980) Artificial surfactant therapy in Hyaline-Membrane Disease. Lancet I:55-59

10. Hallman M, Merritt TA, Jarvenpaa A-L, Boynton B, Mannino F, Gluck L, Moore T, Edwards D (1985) Exogenous human surfactant for treatment of severe respiratory distress syndrome: a randomized clinical trial. J Pediatr 106:963-969

11. Konishi M, Fujiwara T, Naito T, Takeuchi $Y$, Ogawa $Y$, Inukai $K$, Fujimura M, Nakamura H, Hashimoto T (1988) Surfactant replacement therapy in neonatal respiratory distress syndrome: a multi-centre, randomized clinical trial: comparison of high-versus low-dose of surfactant TA. Eur J Pediatr 147:20-25

12. Collaborative European Multicenter Study Group (1988) Surfactant replacement therapy for severe neonatal respiratory distress syndrome: an international randomized clinical trial. Pediatrics $82: 683-691$

13. Ten Centre Study Group (1987) Ten centre trial of artificial surfactant (artificial lung expanding compound) in very premature babies. Br Med J 294:991-996

14. Dunn MS, Shennan AT, Possmayer F (1990) Single- versus multipledose surfactant replacement therapy in neonates of 30 to 36 weeks' gestation with respiratory distress syndrome. Pediatrics 86: $564-571$

15. Lachmann B (1987) The role of pulmonary surfactant in the pathogenesis and therapy of ARDS. In: Vincent JL (ed) Update in intensive care and emergency medicine. Springer, Berlin Heidelberg New York Tokyo, pp 123-134
16. Nosaka S, Sakai T, Yonekura M, Yoshikawa K (1990) Surfactant for adults with respiratory failure. Lancet I:947-948

17. Richman PS, Spragg RG, Robertson B, Merritt TA, Curstedt T (1989) The adult respiratory distress syndrome: first trials with surfactant replacement. Eur Respir J 2 [Suppl 3]:109s - 111s

18. Marraro G (1991) Respiratory emergencies and supplementary surfactant in the treatment of severe RDS in leukaemic adolescents. In: Cosmi EV, Di Renzo GC, Anceschi MM (eds) The surfactant system of the lung: prevention and treatment of neonatal and adult respiratory distress syndrome. Macmillan, London, pp 198-206

19. Joka Th, Obertacke U (1989) Neue medikamentöse Behandlung im ARDS: Effekt einer intrabronchialen xenogenen Surfactantapplikation. Z Herz Thorax Gefäßchir 3 [Suppl 1]: 21s - 24s

20. Lachmann B, Robertson B, Vogel $J$ (1980) In vivo lung lavage as an experimental model of the respiratory distress syndrome. Acta Anaesthesiol Scand 24:231-236

21. Berggren P, Lachmann B, Curstedt T, Grossmann G, Robertson B (1986) Gas exchange and lung morphology after surfactant replacement in experimental adult respiratory distress syndrome induced by repeated lung lavage. Acta Anaesthesiol Scand 30:321-328

22. Robertson B, Lachmann B (1988) Experimental evaluation of surfactants for replacement therapy. Exp Lung Res 14:279-310

23. Lachmann B, Jonson B, Lindroth M, Robertson B (1982) Modes of artificial ventilation in severe respiratory distress syndrome. Lung function and morphology in rabbits after wash-out of alveolar surfactant. Crit Care Med 10:724-732

24. Metcalfe IL, Enhorning G, Possmayer F (1980) Pulmonary surfactant-associated proteins: their role in the expression of surface activity. J Appl Physiol 49:34-41

25. Van Daal GJ, So KL, Gommers D, Eijking EP, Fiévez RB, Sprenger MJ, Van Dam DW, Lachmann B (1991) Intratracheal surfactant administration restores gas exchange in experimental adult respiratory distress syndrome associated with viral pneumonia. Anesth Analg 72:589-595

26. Eijking EP, Van Daal GJ, Tenbrinck R, Luijendijk A, Sluiters JF, Hannappel E, Lachmann B (1991) Effect of surfactant replacement on pneumocystis carinii pneumonia in rats. Intensive Care Med $17: 475-478$

27. Van Daal GJ, Bos JAH, Eijking EP, Gommers D, Hannappel E, Lachmann B (1992) Surfactant replacement therapy improves pulmonary mechanics in end-stage influenza $A$ pneumonia in mice. Am Rev Respir Dis 145:859-863

28. Bos AP, Tibboel D, Hazebroek FWJ, Molenaar JC, Lachmann B, Gommers D (1991) Surfactant replacement therapy in high-risk congenital diaphragmatic hernia. Lancet I:1279

29. Markwell MAK, Haas SM, Bieber LL, Tolbert NE (1978). A modification of the Lowry procedure to simplify protein determination in membrane and lipoprotein samples. Anal Biochem 87:206-210

30. Robertson B, Berry D, Curstedt T, Grossmann G, Ikegami M, Jacobs H, Jobe A, Jones (1985). Leakage of protein in the immature rabbit lung; effect of surfactant replacement. Respir Physiol $61: 265-276$

31. Hallman M, Spragg R, Harrell JH, Moser KM, Gluck L (1982) Evidence of lung function abnormality in respiratory failure. Study of bronchoalveolar lavage phospholipids, surface activity phospholipase activity, and plasma myoinositol. J Clin Invest 70:673-683

32. Gregory TJ, Longmore WJ, Moxley MA, Whitsett JA, Reed CR, Fowler AA, Hudson LD, Maunder RJ, Crim C, Hyers TM (1991) Surfactant chemical composition and biophysical activity in acute respiratory distress syndrome. $J$ Clin Invest 88:1976-1981

33. Petty TL, Reiss OK, Paul GW, Silvers GW, Elkins ND (1977) Characteristics of pulmonary surfactant in adult respiratory distress syndrome associated with trauma and shock. Am Rev Respir Dis $115: 531-536$

34. Pison U, Seeger W, Buchhorn R, Joka T, Brand M, Obertacke U, Neuhof H, Schmit-Neuerburg KP (1989) Surfactant abnormalities in patients with respiratory failure after multiple trauma. Am Rev Respir Dis 140:1033-1039

35. Von Wichert P, Kohl FV (1977) Decreased dipalmitoyllecithin content found in lung specimens from patients with so-called shocklung. Intensive Care Med 3:27-30 
36. Avery ME, Mead J (1959) Surface properties in relation to atelectasis and hyaline membrane disease. Am $\mathrm{J}$ Dis Child 97:517-523

37. Ikegami M, Jobe A, Glatz T (1981) Surface activity following natural surfactant treatment of premature lambs. J Appl Physiol 51:306-312

38. Ikegami M, Jobe A, Jacobs H, Lam R (1984) A protein from airways of premature lambs that inhibits surfactant function. $J$ Appl Physiol 57:1134-1142

39. Ikegami M, Jobe A, Berry D (1986) A protein that inhibits surfactant in respiratory distress syndrome. Biol Neonate 50:121-129

40. Kobayashi T, Curstedt T, Grossmann G, Robertson B (1989) Inhibition of exogenous surfactant in ventilated immature newborn rabbits. Respir Physiol 76:1-12

41. Tierney DF, Johnson RP (1965) Altered surface tension of lung extracts and lung mechanics. J Appl Physiol 20:1253-1260

42. Fuchimukai T, Fujiwara T, Takahashi A, Enhorning G (1987) Artificial pulmonary surfactant inhibited by proteins. J Appl Physiol 62:429-437

43. Holm BA, Notter RH, Finkelstein JN (1985) Surface property changes from interactions of albumin with natural lung surfactant and extracted lung lipids. Chem Phys Lipids 38:287-298

44. Holm BA, Notter RH (1987) Effects of hemoglobin and cell membrane lipids on pulmonary surfactant activity. J Appl Physiol 63:1434-1442

45. Holm BA, Enhorning G, Notter RH (1988) A biophysical mechanism by which plasma proteins inhibit lung surfactant activity. Chem Phys Lipids 49:49-55

46. Keough KMW, Parsons CS, Phang PT, Tweedale MG (1988) Interactions between plasma proteins and pulmonary surfactant: surface balance studies. Can J Physiol Pharmacol 66:1166-1173
47. Taylor Jr FB, Abrams ME (1966) Effect of surface active lipoprotein on clotting and fibrinolysis, and of fibrinogen on surface tension of surface active lipoprotein (with a hypothesis on the pathogenesis of pulmonary atelectasis and hyaline membrane in respiratory distress syndrome of the newborn). Am J Med 40:346-350

48. Holm BA, Venkitaraman AR, Enhorning G, Notter RH (1990) Biophysical inhibition of synthetic lung surfactants. Chem Phys Lipids $52: 243-250$

49. Ikegami M, Jobe A, Jacobs H, Jones S (1981) Sequential treatments of premature lambs with an artificial surfactant and natural surfactant. J Clin Invest 68:491-496

50. Ikegami M, Agata Y, Elkady T, Hallman M, Berry D, Jobe A (1987) Comparison of four surfactants: in vitro surface properties and responses of preterm lambs to treatment at birth. Pediatrics 79:38-46

51. Cockshutt AM, Weitz J, Possmayer F (1990) Pulmonary surfactantassociated protein $\mathrm{A}$ enhances the surface activity of lipid extract surfactant and reverses inhibition by blood proteins in vitro. Biochemistry 29:8424-8429

52. Seeger W, Gunther A, Thede C (1992) Differential sensitivity to fibrinogen inhibition of SP-C-vs. SP-B-based surfactants. Am J Physiol (Lung Cell Mol Physiol) 5:L286-L291

53. Balis JU, Shelley SA, McCue MJ, Rappaport ES (1971) Mechanisms of damage to the lung surfactant system. Ultrastructure and quantitation of normal and in vitro inactivated lung surfactant. Exp Mol Pathol 14:243-262

54. Lachmann B, Hallman M, Bergmann KC (1987) Respiratory failure following anti-lung serum: study on mechanisms associated with surfactant system damage. Exp Lung Res 12:163-180 